\title{
Vergilendirilebilir Gelir ve Gelir Vergisinde Üniter Yapıyı Bozan Uygulamalar $^{1}$
}

Zeynep ARIKAN, Department of Public Finance, Faculty of Economics and Administrative Sciences, Dokuz Eylul University, Turkey; e-mail: zeynep.arikan@deu.edu.tr

Ahmet INNECI, Department of Public Finance, Faculty of Economics and Administrative Sciences, Dokuz Eylul University,Turkey; e-mail:ahmet.inneci@deu.edu.tr

\section{Taxable Income and the Practices Disrupting the Structure of Global System in Income Tax $^{2}$}

\begin{abstract}
Taxable income is the essence of the tax system. Determining the scope of taxable income is one of the important subject to be emphasized for providing the efficiency in taxation. There are two theories deal with determination of taxable income: "Source Theory" and "Net Increasing Theory". In practice, countries base on different theories in determining taxable income. Income tax systems are classified as global, schedular and mixed income tax systems. Taxable income is determined basis of source and net increasing theories in income tax systems. Although the global tax system is applied in Turkey, it is observed that some practices cause deviations from the system and contrary to global structure. The excessive expansiyon of the scope of this practices cause damage the tax system, decline in tax revenues, reduce the desire about voluntary tax compliance and violate the rights of taxpayers. In this study, it is focused on the concepts of income and taxable income. Besides, it is examined the practices caused deviations from global tax system for determining the ideal limits of taxable income and it is focused on the results of the deviations from global tax system and it is offered the solutions in this study.
\end{abstract}

Keywords $\quad$ : Taxable Income, Tax System, Global Tax System.

JEL Classification Codes : $\quad$ H20, H24, K34.

I Bu makale Sosyoekonomi Derneği ile Hacettepe Üniversitesi Piyasa Ekonomisini ve Girișimciliği Gelişstirme Merkezi tarafindan Almanya'nin Münih şehrinde, 29-30 Ekim 2015 tarihlerinde düzenlenen "Birinci Uluslararası Sosyoekonomi Derneği Yıllık Buluşması"nda sunulan çalışmanın gözden geçirilmişs ve genişletilmiş halidir.

2 This article is the revised and extended version of the paper presented in "First International Annual Meeting of Sosyoekonomi Society" which was held by Sosyoekonomi Society and CMEE - Center for Market Economics and Entrepreneurship of Hacettepe University, in Munich/Germany, on October 29-30, 2015. 


\section{$\ddot{\mathbf{O} z}$}

Vergilendirilebilir gelir, vergi sistemlerinin özünü oluşturmaktadır. Vergilendirmede etkinliği sağlayabilmek açısından vergilendirilebilir gelirin kapsamının belirlenmesi, üzerinde durulması gereken önemli konulardan biridir. Vergilendirilebilir gelirin belirlenmesinde "kaynak teorisi" ve "safi artış teorisi" olmak üzere iki teori bulunmaktadır. Uygulamaya bakıldığında vergilendirilebilir gelirin belirlenmesinde ülkelerin farklı teorileri esas aldıkları görülmektedir. Gelir vergisi sistemleri ise üniter, sedüler ve bileşik gelir vergisi sistemleri şeklinde sınıflandırılmaktadır. Gelir vergisi sistemlerinde kaynak ve safi artış teorileri esas alınarak vergilendirilebilir gelir belirlenmektedir. Türkiye'de üniter gelir vergisi sistemi uygulanmakla birlikte, kimi uygulamaların sistemden sapmalara neden olduğu ve üniter yapıya ters düştügü görülmektedir. Bu uygulamaların kapsamının aşırı derecede genişlemesi vergi sisteminin erozyona uğramasına, vergiye gönüllü uyum konusunda isteklerin azalmasına, vergi gelirlerinin düşmesine, mükellef haklarının zedelenmesine neden olmaktadır. Çalışmada gelir ve vergilendirilebilir gelir kavramları üzerinde durulmuştur. Vergilendirilebilir gelirin ideal sınırlarını belirlemek açısından üniter gelir vergisi sistemine ters düşen uygulamalara değinilerek, bunların sonuçları üzerinde durulmuş ve sistemi etkinleştirici çözüm önerileri getirilmeye çalışılmıştır.

Anahtar Sözcükler $\quad$ : Vergilendirilebilir Gelir, Vergi Sistemi, Üniter Vergi Sistemi.

\section{Giriş}

Türk vergi sisteminde çağdaş anlamda bir gelir vergisi ilk kez 1950 yılında gerçekleştirilen vergi reformu ile yürürlüğe girmiştir. İlk dönemlerde vergilendirilebilir gelir kavramı üzerinde çok fazla durulmamıştır. İlk kez 4369 sayılı Kanun'la yapılan düzenlemeden sonra vergilendirilebilir gelirin ne olması gerektiği konusunda tartışmalar başlamış ve söz konusu kanun ile gelirin tanımı değişmiş, verginin konusu genişletilmiştir. Kısacası gelirin kavranması hedefleri önem kazanmıştır. Zira vergilendirilebilir gelir kavramına yaklaşım ve bu gelirin nasıl ve ne ölçüde vergilendirileceği, sistemin temelini oluşturmakta ve sistemin başarısının belirleyicisi olmaktadır.

Dünyanın farklı ülkelerinde farklı gelir vergisi sistemleri uygulansa da, temelde yatan esas düşünce geliri, ülkelerin yapısına göre tam olarak kavrayacak bir şekilde vergilendirmektir. Bu nedenle uygulama şekilleri açısından gelir vergisi sistemleri, "sedüler gelir vergisi sistemi", "üniter gelir vergisi sistemi" ve her iki sistemi birlikte esas alan "bileşik gelir vergisi sistemi" şeklinde bir ayrıma tabi tutulmaktadır. Gelir vergisi sistemleri de kaynak ve safi artış teorilerinin gelir tanımlarından yola çıkarak vergilendirilebilir geliri belirlemektedirler.

Ülkeler ekonomik, sosyal, mali, siyasi ve kültürel yapılarına uygun gelir tanımı yapmalarına karşılık, bu tanım teorik düzeyde kalmakta ve çeşitli zorluklar ve nedenlerden dolayı tanımlanan vergilendirilebilir gelir kavramına tam olarak ulaşılamamaktadır. $\mathrm{Bu}$ durum sistemde belirlenen vergisel hedeflerin amacından sapmasina neden olmaktadir. Böylelikle ekonomik, sosyal ve siyasi hayatın vazgeçilmez araçlarından biri olan vergi ile istenen hedeflere tam olarak ulaşılamamaktadır.

Ödeme gücünü kavramaya yönelik üniter gelir vergisi sisteminde toplama yapılmas1 sistemin bir gereğidir. Türk vergi sisteminde Gelir Vergisi Kanunu (GVK)'nun 85. maddesinde de gelirin toplanması ve beyanına, 86. maddesinde ise toplama yapılmayan 
Arıkan, Z. \& A. İnneci (2016), "Vergilendirilebilir Gelir ve Gelir Vergisinde

Üniter Yapıyı Bozan Uygulamalar”, Sosyoekonomi, Vol. 24(30), 11-28.

hallere ilişkin düzenlemelere yer verilmiştir. Ancak uygulamada çeşitli nedenlerle beyan diş1 bırakılan gelirlerin kapsamının çok geniş tutulması, gelir vergisinde üniterliğin sağlanmasına engel olmaktadır.

Çalışmada öncelikle gelir ve vergilendirilebilir gelir kavramları ele alınmaktadır ve vergilendirilebilir gelirin tespitinde kullanılan teoriler incelenmektedir. Daha sonra gelir vergisi sistemleri incelenerek, Türk Gelir Vergisinin üniter yapısına değinilmekte, sistemden sapmalar incelenmekte ve sistemden sapmaların sonuçlarına değinilerek, sistemin üniterliğinin sağlanmasına yönelik öneriler sunulmaktadır.

\section{Gelir Kavramı}

Sözlük anlamı itibariyle gelir "bir ekonomik birimin belli bir süre içinde kazandırdığı aylık, kira vb. getiri, varidat, irat" anlamlarına gelmektedir (www.tdk.gov.tr). İktisadi anlamada ise gelir, bir kimsenin belirli bir devre başında ve sonunda aynı zenginlikte kalmak koşuluyla o devre içinde tüketebileceği mal ve hizmetlerin toplamıdır (Aksoy, 1998: 324). Bunun yanında, belirli bir zaman kesiti içinde alım gücünde artış şeklinde ortaya çıkan bir akım (Öncel vd., 2012: 238), üretim faktörlerinin üretim sürecine sokulmaları sonucunda elde edilen değerler akımı (Tosuner \& Arıkan, 2016: 10) şeklinde de tanımlanmaktadır. Kısacası kişinin iktisadi gücündeki artışı ifade eder. Bu artış iktisadi sürece iktisadi faktör katılımı ile olabileceği gibi, bu katılım olmadan da gerçekleşebilir.

\section{Vergilendirilebilir Gelir Kavramı}

Gelir iktisadi bir kavramdır ve bu nedenle iktisatta değişik açılardan farklı yönleriyle incelenmiştir. Ancak gelir vergisinin konusunun yanı sıra matrahını da oluşturan gelirin vergi hukuku ve vergi tekniği açısından ayrıca tanımlanması gerekmektedir. Çünkü iktisadi gelir tanımının vergilemede aynen alınması uygulamada bir takım sorunlara neden olabilecektir. Bu nedenle mali açıdan ayrı bir inceleme konusu yapılmıştır (Nadaroğlu, 1996: 338). Her ne kadar iktisadi anlamda gelir tanımı ile vergilendirilebilir gelir yani mali gelir kavramı tanım olarak birbirine yaklaşmış olsalar da, vergilendirilebilir gelir kazanç ve iratların bir yıllık toplamı olarak kabul edilmekte ve iktisadi gelir kavramından farklı olarak geçmiş yıl zararlarını da dikkate almaktadır (Tosuner \& Arıkan, 2016: 11). Aslında mali gelir, vergi kanunlarında yapılan gelir tanımını ifade etmektedir. Yani vergi kanunları iktisadi anlamda gelir kavramı 1şı̆̆ında bir kısım geçici gelirleri de dikkate alarak vergiye tabi gelirleri açıkça saymakta ve vergiye tabi gelirleri açıkça belirlemektedir (Erginay, 1998: 88). Vergilendirilebilir gelir, gayrisafi gelirden bir takım indirimlerin yapılması, zararların mahsubu vb. sonucunda ortaya çıkan tutarı ifade etmektedir. Vergilendirilebilir gelir kavramı ve vergilendirilebilir gelirin kapsamı, ülkelerin gelir vergisi sistemlerinin oluşmasında büyük önem arz etmektedir.

Gelir vergisinde verginin konusu olan gelirin yani vergilendirilebilir gelirin belirlenmesinde literatürde "Kaynak Teorisi" ve "Safi Artış Teorisi" olmak üzere iki teori bulunmaktadır. Bu teoriler esas alınarak gelir tanımı yapılmakta, vergilendirilebilir gelirin kapsamı ve sınırları belirlenmektedir. 


\subsection{Kaynak Teorisi (Dar Anlamda Gelir)}

İlk olarak Alman iktisatçılardan Von Hermann tarafından ileri sürülen kaynak teorisi, İtalyan ve Fransız iktisatçılar tarafindan da benimsenmiştir. (Nadaroğlu, 1996: 338). Bu teoriye göre gelir; belli bir üretim faaliyetine katılma sonucunda elde edilen ekonomik değerlerdir (Öncel vd, 2012: 239). Başka bir deyişle, üretim faktörlerinin (emek, sermaye, doğal kaynak, teşebbüs) üretim sürecine sokulmaları sonucunda faktör sahiplerinin elde ettikleri değerler akımı (ücret, faiz, rant, kar) gelir olarak kabul edilmektedir (Bulutoğlu, 1976: 66). Bu teoride gelirin iki temel özelliği bulunmaktadır. Bunlardan ilki elde edilen gelirin sürekli olması gereğidir. Diğeri ise gelirin üretim faktörlerinden birinin veya birden fazlasının üretim sürecine sokulması sonucunda elde edilmesi zorunluluğudur (Tosuner \& Arıkan, 2016: 11). Bu nedenle üretim faktörlerinin kendi değerlerindeki artışlar ile üretim faktörlerine bağlı olmaksızın elde edilen değerler ve varlıklar (miras, bağış, piyango vb.) gelir sayılmamaktadır, çünkü bunlar devamlı değillerdir ve arızi bazı sebepler dolayısıyla elde edilirler (Ortaç, 2000: 27; Nadaroğlu, 1996: 338).

$\mathrm{Bu}$ teoriye göre gelir nakdi olabileceği gibi ayni de olabilmektedir. Faktör sahiplerinin üretim faktörlerini piyasaya arz etmeyip kendi tükettikleri mal ve hizmetlerin üretiminde kullanmaları halinde de elde edilen değerler gelir sayılmaktadır. Örneğin bir kimsenin evinde kendisinin oturması, bahçesinin ürünlerini kendisinin kullanması sonucunda elde ettiği faydalar gelirdir. Yani kaynak teorisinde kişinin “öztüketim”i gelir sayılmaktadır (Bulutoğlu, 1976, s. 67). Bu teoride safi gelire ulaşmak için ayni veya nakdi olarak elde edilen gayrisafi gelirden, bu gelirin elde edilmesi için yapılan giderler ve ayrılan amortismanların indirilmesi gerekmektedir.

Kaynak teorisinde gelirin tanımlanmasında süreklilik ve bir üretim faktörüne bağlılık söz konusudur. Bunun doğal bir sonucu olarak da kimi gelirler (transfer ödemeleri, arızi kazançlar gibi) vergilendirilebilir gelirin kapsamına dâhil edilememektedir. Yani aslında vergi ödeme gücüne sahip olan biri vergilendirilebilir gelirin belirlenmesinde kaynak teorisi kullanılması halinde vergilendirilemeyecektir. Bu da vergilemede adalet, eşitlik ve ödeme gücü ilkelerine aykırılık teşkil etmektedir. Bunun yanında kaynak teorisinin yaptığı gelir tanımının çeşitli unsurlara bağlanarak dar kapsamlı bir şekilde yapılması; vergi tabanının daralmasına, mükelleflerin gelir kapsamında olmayan faaliyetlerde bulunmalarına neden olmaktadır. Bunun doğal bir sonucu olarak, kayıt dışı ekonominin boyutları artmakta ve devlet eliyle bazı gelir türlerinin vergi dışı bırakılması gelir dağılımının bozulmasına neden olmaktadır (Ferhatoğlu, 2003).

\subsection{Safi Artış Teorisi (Geniş Anlamda Gelir)}

İlk olarak Alman iktisatçılardan George Von Schanz tarafindan ifade edilen bu teoriye göre gelir, belli bir dönemde servette meydana gelen net artış şeklinde tanımlanmaktadır (Ortaç, 2000: 28). Net artış teorisi olarak da ifade edilen bu teoride gelirin, kaynak teorisinde yapılan gelirin aksine, belirli bir kaynaktan elde edilmesi ve sürekli olması özellikleri bulunmamaktadır. 
Arıkan, Z. \& A. İnneci (2016), "Vergilendirilebilir Gelir ve Gelir Vergisinde

Üniter Yapıyı Bozan Uygulamalar”, Sosyoekonomi, Vol. 24(30), 11-28.

Bu teoriye göre servette net bir artış meydana getiren her türlü kazanç ve iratlar gelir kapsamına girmektedir. Bu teoriye göre gelir kişinin belirli bir dönemde servetinde meydana gelen net artış ile o dönemde tüketime ayırdığı harcamalarından oluşmaktadır (Nadaroğlu, 1996: 338). Dolayısıyla süreklilik gösteren kaynaklardan elde edilen değerler yanında, sürekli ve belli olmayan zamanlarda arızi şekilde elde edilen değerler ile herhangi bir üretim faktörüne bağlı olmaksızın elde edilen değerler de gelir kavramına dâhil edilmektedir. Kaynak teorisinin aksine milli piyango, miras ve bağış gibi gelirler safi artış teorisinde gelire dâhil edilmektedir (Turhan, 1987: 131). Kaynak teorisinde olduğu gibi bu teoride de öztüketim gelir sayılmaktadır.

Safi artış teorisi kaynak teorisine göre geliri geniş bir şekilde kavramaktadır. Bu da vergi tabanının genişlemesine imkân tanımaktadır. Bunun yanında vergi adaleti bakımından daha uygundur. Ancak safi artış teorisi uygulamada vergi tekniği açısından bir takım zorlukları beraberinde getirmektedir. Öncelikle varlıkların toplam değerindeki değişmeleri tespit etmek zordur. Gerçekten de iktisadi sistemde görülen sürekli fiyat değişikliklerinde servette meydana gelecek artış ve azalışların (özellikle menkul ve gayrimenkul malların değerlerindeki artış ve azalışların), servete giren ve çıkan değerlerin izlenmesi zordur (Nadaroğlu, 1996: 339; Erginay, 1998: 87). Bunun yanında bireyler tarafından gerçekleştirilen tüketimlerin (öztüketim dâhil) ve değerlerinin belirlenmesi idari bakımından büyük zorluklar oluşturmaktadır. Zira her türlü tüketim harcamaları ile kendi varlıklarından ve emek gücünden sağlanmak suretiyle kullanılan mal ve hizmetlerin değerlerinin hesaplanması gerekecektir (Bulutoğlu, 1976: 69; Aksoy, 1998: 326).

Gerek kaynak teorisi gerekse safi artış teorisi çeşitli yönleriyle eleştiri konusu yapılmaktadır. Bu nedenle uygulamada birçok ülke kaynak teorisi ile safi artış teorisini birlikte kullanarak karma bir sistem oluşturmuşlardır. Bu sistemde hangi teorinin daha etkin olduğu zamana, mekâna ve ülkelerin ekonomik ve kültürel yapılarına göre farklılık göstermektedir (Turhan, 1987: 132; Ortaç, 2000: 30-31, Tosuner \& Arıkan, 2016: 13). Bazı ülke uygulamalarında kaynak teorisine, diğer bazı ülkelerde ise safi artış teorisine ağırlık veren düzenlemelerin yer aldığı görülmektedir. Ancak, özellikle gelişmiş ülkelerin uygulamalarında, vergilendirmenin mümkün olduğunca safi artış teorisinde tanımlanan geliri kavrayacak düzenlemelere göre yapıldığı dikkat çekmektedir. Bu amaçla, bazı ülkeler gelir unsurlarını kaynağına göre sayarken mümkün olabildiğince fazla sayıda gelir sedülü (unsur) belirlemişler veya sedül sayısını az tutmakla birlikte sedüllere giren gelir unsurlarının kapsamını geniş tutmuşlardır. Böylece, görünüşte kaynak teorisine uygun düzenlemeler yapmakla birlikte, gerçekte safi artış teorisindeki gelir tanımlamasına yaklaşmışlardır (4369 Sayılı Kanun Gerekçesi, 1998: 364).

\section{3. Ülke Uygulamaları}

Vergilendirilebilir gelirin tespiti benzer yönleri olmasına karşılık ülkeden ülkeye değişiklik göstermektedir. Ülkelerin vergi kanunlarında vergilendirilebilir gelirin tanımına ilişkin farklı hükümler yer almakta, vergilendirilebilir gelir mümkün olduğu kadar geniş bir şekilde kavranmaya çalışılmaktadır. Aşağıda Almanya, İngiltere, Fransa, Amerika Birleşik Devletleri, İspanya, İtalya ve Portekiz'de vergilendirilebilir gelirin tespitine ilişkin bilgilere 
yer verilmiştir. Ülke uygulamaları incelendiğinde vergilendirilebilir gelirin tespitinde ülkelerin uyguladıkları sistemin gelişmişlik düzeyi ile ilişkisinin olmadığı görülmektedir. $\mathrm{Bu}$ ülkelerde gelirin tespitinde hangi teori kullanılırsa kullansın temel amaç geliri geniş bir şekilde ele alarak vergilendirilebilir gelirin kapsamını geniş tutmaktır. Bazı ülkeler kaynak teorisini baskın bir şekilde uygularken diğer bazıları safi artış teorisini baskın bir şekilde uygulamaktadirlar.

\subsubsection{Almanya}

Alman Gelir Vergisi Kanunu'nda verginin konusunu oluşturan kaynaklar 7 bent halinde sayılmıştır. Buna göre gelir vergisinin konusunu;

- Ziraat ve ormancılık gelirleri,

- Ticari gelirler,

- Serbest meslek gelirleri,

- Ücretler,

- Sermaye gelirleri,

- Kiralama ve benzeri gelirler,

- Diğer gelirler (spekülatif kazançlar, düzenli niteliğe sahip nafaka gibi gelirler ve diğer çeşitli gelirler)

oluşturmaktadır (<http://www.gesetze-im-internet.de/estg/_2.html〉, 25.11.2015).

Gelir unsurlarının tek tek sayılarak belirlenmesi Alman Gelir Vergisi'nin kaynak teorisini esas aldığı izlenimi vermekle birlikte, gelir unsurları içinde yer almayan kimi gelirlerin yedinci gelir unsuru olan "diğer gelirler" içinde sayılması, Alman Gelir Vergisi uygulamasının kaynak ve safi artış teorilerini birlikte esas alan karma bir yapıya sahip olduğunu göstermektedir (Ferhatoğlu, 2003). Almanya'da elde edilen gelirlerden vergi kanunlarında belirtilen bu gelirlerle bağlantılı olan giderler çıkartılır. Ücretler yıl bazında hesaplanarak aylık stopajlar şeklinde ödeme yapılır. Gerçek kişilerin ücret dışında herhangi bir geliri olması halinde yıllık beyanname vermesi zorunludur (<http://www.ecovis.com/fokus-tuerkei/alman-vergi-sistemi-hakknda/>, 25.11.2015)

\subsection{2. İngiltere}

İngiliz Gelir Vergisi sisteminde gelir kategorilere ayrılmaktadır. Buna göre verginin konusuna giren gelir unsurları aşağıdaki gibi gruplandırılmaktadır (<http://www.legislation.gov.uk>, 25.11.2015);

- Kategori A: Gayrimenkul Sermaye İratları

- Kategori B: Tarım ve Ormancılık Gelirleri

- Kategori C: Devlet Tahvili Faiz Gelirleri

- Kategori D: 6 alt gruba ayrilmaktadır. 
- Grup 1: Ticari Kazançlar

- Grup 2: Mesleki Gelirler Gibi Diğer Gelirler

- Grup 3: Faiz Gelirleri ve Diğer Düzenli Gelirler

- Grup 4: Denizaşırı Tahvil ve Hisse Senedi Gelirleri

- Grup 5: Denizaşırı Elde Edilen Ücretler

- Grup 6: Bunların Dışında Kalan ve Diğer Gruplarda Olmayan Gelirler

- Kategori E: Ücretler ve Emeklilik Gelirleri

- Kategori F: Kar Payları ve Şirketlerden Elde Edilen Diğer Gelirler

İngiliz Gelir Vergisi Yasasında yapılan gelir unsurlarının gruplandırılmasına bakıldığında "Grup 6" da her ne kadar diğer gelirleri de içine alacak şekilde geniş bir tanımlamaya gidilmiş olsa da, uygulamada kaynak teorisinin safi artış teorisine kıyasla baskın bir şekilde kabul edildiği söylenebilir.

\subsubsection{Fransa}

Fransa'da vergilendirilebilir gelir kategorileri şu şekildedir:

- Ticari kazançlar,

- Zirai kazançlar,

- Gayrimenkul sermaye iratları,

- Menkul sermaye iratları,

- Ücretler,

- Ticari olmayan diğer gelirler (serbest meslek kazançları ile diğer gelir unsurlarına girmeyen gelirler),

- Şirketlerden elde edilen gelirler,

- Sermaye kazançları.

Fransa Gelir Vergisi'nde gelirin bir tanımı yapılmamakla birlikte gelir kapsamına dâhil olan unsurların tek tek belirlenerek kategorilere ayrılması Fransız Gelir Vergisi'nde kaynak teorisinin esas alındığını göstermektedir.

\subsubsection{Amerika Birleşik Devletleri}

ABD Gelir Vergisi Kanunu'nun 61. maddesine göre gelir, kanuni olsun veya olmasın, yani kaynăg 1 ne olursa olsun elde edilen gelirin tamamıdır. Kanunun 61. maddesinde belirli gelir unsurları sayılmakla birlikte bunlar sınırlayıcı değildir yani kanunda sayılanlar ile sınırlı olmaksızın bir kişinin bir yıl içinde elde ettiği tüm gelirler verginin konusuna girmektedir. İlgili madde hükmünde sayılan gelir unsurları şunlardır (<https://www.law.cornell.edu/uscode/text/26/61>, 25.11.2015):

- Hizmet bedelleri (ücretler, komisyonlar, maddi yardımlar vb.), 
- Ticari kazançlar,

- Zirai kazançlar,

- Faizler,

- Kiralar,

- Gayrimaddi hak gelirleri,

- Kar payları,

- Nafaka ve diğer benzeri ödemeler,

- Ücretler,

- Hayat sigortası ve bağış sözleşmelerinden elde edilen gelirler,

- Emeklilik gelirleri,

- Ortaklık gelirinden alınan paylar,

- Ölüme bağli gelirler,

- Varlığa bağlı gelirler.

Yukarı da açıklandığı gibi ABD Gelir Vergisi Kanunu'na göre kanunda sayılanlarla sınırlı olmaksızın elde edilen tüm gelirler gelir vergisinin konusuna girmektedir. Bu yönüyle ABD gelir vergisi sisteminin geliri geniş anlamıyla kavradığı ve vergilendirilebilir gelirin tespitinde safi artış teorisini esas aldığı söylenebilir. Amerika vergi kanunları vatandaşlarını kişisel bağ kavramı ile vergilendirmektedir. Amerika vatandaşları ister yurtiçinde ister yurtdışında gelir elde etmiş olsun Amerika vergi kanunlarına göre vergilendirilmektedir (<amerikanvergisi.com〉, 25.11.2015).

\subsection{5. İspanya}

İspanya'da vergilendirilebilir gelir kategorileri şu şekildedir (EY, 2015-2016, s. 1212-1213):

- Ücret gelirleri,

- Ticari kazançlar,

- Serbest meslek kazançları,

- Gayrimenkul sermaye iratları,

- Menkul sermaye iratları.

İspanya gelir vergisinde gelir unsurlarına dikkat edildiğinde kanun koyucu gelir unsularını tek tek saymak suretiyle belirlemiştir. Gelir unsurlarının üretim faktörleri itibariyle belirlenmesi kaynak teorisinin baskın bir şekilde uygulandığını göstermektedir. Nitekim diğer ülke örneklerinde yer alan gelir unsurlarından "diğer kazançlar" gibi bir unsurun olmaması safi artış teorisinin temel olarak esas alınmadı̆̆ının bir göstergesidir. 


\subsection{6. İtalya}

İtalya gelir vergisinde gelir unsurları ücret, menkul ve gayrimenkul sermaye iratları, ticari kazanç, serbest meslek kazancı ve çeşitli gelirlerden oluşmaktadır. Çeşitli gelirler kategorisinde ise yurt dışında bulunan gayrimenkullerden, entelektüel sermayeden ve arızi nitelikli ticari faaliyetlerden elde edilen gelirler yer almaktadır. İtalya gelir vergisi sisteminde gelir unsurları tek tek sayılmıştır. Bu nedenle gelirin tanımlanmasında kaynak teorisinin baskın olduğu söylenebilir (Ferhatoğlu, 2003).

\subsubsection{Portekiz}

Portekiz gelir vergisinde gelir unsurları ücret, ticari kazanç, serbest meslek kazancı, yatırım geliri, menkul sermaye iradı, sermaye kazancı, emekli maaşları ve bahis ve kumar kazançlarından oluşmaktadır (PKF, 2013: 4). Bu yönüyle gelirin tespitinde kaynak teorisinin baskın olduğu söylenebilir. Gelir unsurları tek tek sayılmak suretiyle belirlenmiştir. Vergilendirilebilir gelir belirlenirken gelir unsurları itibariyle bazı indirimler söz konusu olabilmektedir. Örneğin sağlık ve eğitim harcamalarının belirli bir yüzdesi indirim konusu yapılabilmektedir.

\subsection{Türk Gelir Vergisinde Vergilendirilebilir Gelir Kavramı}

Gelir, 193 sayılı Gelir Vergisi Kanunu (GVK)'nun 1. maddesinde tanımlanmaktadır. $\mathrm{Bu}$ maddeye göre "gelir, bir gerçek kişinin bir takvim yılı içinde elde ettiği kazanç ve iratların safi tutarı"dır. GVK'nın 2. maddesinde ise ticari kazançlar, zirai kazançlar, ücretler, serbest meslek kazançları, gayrimenkul sermaye iratları, menkul sermaye iratları ve diğer kazanç ve iratlar, gelir kapsamına dâhil olan kazanç ve iratlar (gelir unsurları) olarak tek tek sayılmaktadır. GVK'nın 1. ve 2. maddeleri birlikte değerlendirildiğinde iktisadi anlamda yapılan gelir tanımından farklı bir gelir tanımının (vergilendirilebilir gelir) ortaya çıktığı görülmektedir. Türk Gelir Vergisinde gelirin vergilendirilmesi için, bir takvim y1lı içinde bir gerçek kişi tarafından elde edilmesi ve GVK'nın 2. maddesinde sayılan gelir unsurlarından birine dâhil olması gerekmektedir. Bu nedenle Türk Gelir Vergisinde vergiye tabi gelirin sınırlarını GVK'nın 1. maddesinden çok 2. maddesi belirlemektedir.

Bir kazanç ya da iradın gelir unsurlarından herhangi birine dahil olmaması halinde, özünde gelir niteliği taşısa bile, gelir vergisi kapsamı dışında tutulması gerekecektir (Öncel vd., 2012: 241). Bu nedenle yapılan gelir tanımı ve kapsamı nedeniyle vergi gelirlerinde bir azalma söz konusu olmaktadır. Bazı gelirlerin gelir vergisi kapsamında vergilendirilmemeleri diğer kanunlar çerçevesinde vergilendirilmelerine engel değildir. Gelir vergisi kapsamında vergilendirilmeyen bazı gelirler diğer vergi kanunlarında verginin konusuna girebilir ve böylece vergilendirilebilir. Bunlara bağış, miras, piyango gibi yollarla elde edilen gelirler örnek olarak gösterilebilir. Bunlar özünde gelir niteliği taşımakla birlikte gelir vergisinin kapsamına girmemekte ve dolayısıyla gelir vergisi kapsamında vergilendirilmemektedir. Ancak bunlar Veraset ve İntikal Vergisi Kanunu çerçevesinde vergilendirilebilecektir. 
GVK'nın 2. maddesinde sayılan gelir unsurlarının ilk altısında (ticari, zirai ve serbest meslek kazançları ile menkul ve gayrimenkul sermaye iratları), üretim faktörleri üretim sürecine sokulmaktadır ve böylece çeşitli kazanç ve iratlar elde edilmektedir (örneğin ücret, emek faktörünün, menkul sermaye iradı ise sermaye faktörünün bir getirisidir). Elde edilen kazanç ve iratların ilk altı gelir unsuru kapsamına dâhil edilip vergilendirilmesi için "süreklilik" arzetmeleri gerekmektedir. Ancak yedinci gelir unsuru olan "diğer kazanç ve iratlar" da "kısmen" safi artış teorisi esas alınmaktadır. Çünkü bu gelir unsurunun kapsamına bütün değer artışları değil, bazı değer artışları (GVK mük. md. 80) ile süreklilik arzetmeyen, arızi nitelikli, bazı gelirler (GVK md. 82) girmektedir. Görüldüğü gibi gelir unsurlarının ilk altısında kaynak teorisi, yedinci gelir unsuru olan "diğer kazanç ve iratlar"da ise kısmen safi artış teorisi esas alınmaktadır. Bu yönüyle Gelir Vergisi Kanunumuzun her iki teoriyi de esas alan karma bir sisteme sahip olduğu söylenebilir (Arslan, 2012: 12) ${ }^{3}$.

GVK'nın 1. maddesine göre "Gerçek kişilerin gelirleri gelir vergisine tabidir. Gelir bir gerçek kişinin bir takvim yılı içinde elde ettiği kazanç ve iratların safi tutarıdır." Yapılan tanımdan gelirin bir takım özelliklere sahip olduğu anlaşılmaktadır. Bu tanıma göre gelir; kişiseldir, yıllıktır, elde edilmiş olması gerekir, gerçektir ve kazanç ve iratların safi tutarıdır. Türk Gelir Vergisinde yapılan gelir tanımı gelirin kapsamını belirlemekten çok aslında gelirin özelliklerini belirleyen bir tanımdır. Türk vergi sisteminde her türlü kazanç ve irat vergilendirilememektedir. Çünkü gelir doğmakta ancak verginin konusuna girmemektedir. Geliri mali anlamda tam olarak belirleyip sınırları çizilememektedir. Gelirin mali anlamda tam olarak kavranamaması kayıp kaçakların büyük boyutlara ulaşmasına neden olmaktadır.

\section{Gelir Vergisi Sistemleri}

Dünyada gelir vergisi uygulama şekillerine bakıldığında üç farklı gelir vergisi sisteminin uygulandığı görülmektedir. Bu uygulama şekilleri; üniter, sedüler ve bileşik gelir vergisi sistemleridir.

\section{1. Üniter Gelir Vergisi Sistemi}

Üniter gelir vergisi sisteminde, mükelleflerin farklı kaynaklardan elde ettikleri gelirleri elde edilen kaynak türüne bakılmaksızın bir arada toplanarak vergilendirme

3 22.07.1998 tarihli ve 23417 Sayll (mükerrer) Resmi Gazetede yayımlanan 4369 Sayılı Kanunun 24. maddesi ile yapılan düzenleme, Gelir Vergisi Kanunumuzda yapılan gelir tanımını değiştirmiştir. Buna göre gelir, bir gerçek kişinin bir takvim yılı içinde elde ettiği tasarruf veya harcamalarına kaynak teşkil eden her türlü kazanç ve iratların safi tutarıdır. Yapılan bu gelir tanımı ile Kanunumuzun geliri geniş anlamda tanımladı̆̆ söylenebilir. Çünkü yapılan bu tanımla, gelir vergisi sistemimizde gelirin tespitinde kaynak teorisinin yerini safi artış teorisinin alması hedeflenmiştir. Ancak 4369 sayılı Kanun ile yapılan bu değişikliğin uygulanması 14.08.1999 tarihli ve 23786 Sayılı Resmi Gazetede yayımlanan 4444 Sayll Kanunun Geçici 56. maddesi ile 2003 yllına kadar ertelenmiştir. Daha sonra ise 09.01.2003 tarihli ve 24988 Sayll Resmi Gazetede yayımlanan 4783 Sayılı Kanun ile 4369 Sayll Kanunda yapılan gelir tanımı iptal edilerek, 193 sayll Gelir Vergisi Kanunumuzda yapılan gelir tanımı tekrar kabul edilmiştir. 
Arıkan, Z. \& A. İnneci (2016), "Vergilendirilebilir Gelir ve Gelir Vergisinde

Üniter Yapıyı Bozan Uygulamalar”, Sosyoekonomi, Vol. 24(30), 11-28.

işlemleri yapılmaktadır. Safi gelire ulaşmak için zarar varsa karlara mahsup edilir ve mükellefin kişisel ve ailevi durumu da dikkate alınarak bir takım indirimler yapılır (Tosuner \& Arıkan, 2016: 15-16). Bu indirimlerin amacı vergilemede ödeme gücü ile adalet ilkesinin sağlanmasıdır. Gelir vergisinin üniterliği yani gelirlerin bir arada toplanıp vergilendirilmesi aslında vergilendirme açısından bir amaç değil, vergilemede ödeme gücü ve adalet ilkelerinin sağlanmasına yönelik bir araçtır.

Üniter gelir vergisinin tek elemanlı ve çift elemanlı üniter gelir vergisi sistemi olmak üzere iki tür uygulama şekli vardır. Tek elemanlı üniter gelir vergisi sisteminde, mükellefin tüm kaynaklardan elde ettiği gelirin safi tutarına artan oranlı bir vergi tarifesi uygulanır (Turhan, 1987: 129). "Cermen Tipi”" gelir vergisi olarak da adlandirılan tek elemanlı gelir vergisi sitemi Türkiye'de uygulanan sistemdir. Bunun yanında Fransa, Almanya ve Hollanda gibi ülkelerde de uygulanmaktadır. Çift elemanlı üniter gelir vergisi sisteminde ise tüm kaynaklardan toplanan safi gelir ikili bir vergi tarifesi uygulanarak vergilendirilmektedir. Safi gelire öncelikle tek oranlı bir tarife uygulanır, gelirin belirli bir seviyeyi aşması halinde, aşan kısma artan oranlı bir vergi tarifesi daha (surtax) uygulanır (Tosuner \& Arıkan, 2016: 16). “Anglosakson Tipi”" gelir vergisi de denen çift elemanlı gelir vergisi sistemi İngiltere ve ABD gibi ülkelerde uygulanmaktadır (Ortaç, 2000: 5).

Üniter gelir vergisi sistemindeki yüksek artan oranlı vergi tarifeleri nedeniyle sermaye gelirleri alanında artan vergiden kaçınma ve vergi kaçakçılığı, ülkelerin üniter yapıyı terk etmelerine ve sermaye gelirleri alanında ayrı bir vergi uygulamasına gitmelerine neden olmaktadır (Hamaakers, 2003: 47).

\subsection{Sedüler Gelir Vergisi Sistemi}

Sedüler gelir vergisinde mükelleflerin çeşitli kaynaklardan elde ettikleri gelirler, üniter sistemde olduğunun aksine bir araya toplanarak değil, her bir gelir unsuru bakımından ayrı ayrı vergilendirilir. Sedüler gelir vergisi sisteminde vergi oranı gelirin her bir unsuruna ayrı ayrı uygulanmaktadır. Brüt gelir her bir gelir unsurunda ayrı ayrı tespit edilir ve indirimler her gelir unsuruna göre ayrı ayrı değerlendirilir. Vergi oranları her bir gelir unsurunda farklılık gösterebilmektedir (Burns \& Krever, 1998: 1). Bu sistemde yükümlünün bir kaynaktan zarar etmesi halinde bu zararlar diğer kaynaklardan elde edilen karlara mahsup edilmemektedir. Her bir gelir unsuru birbirinden bağımsız değerlendirilmektedir. Bu yönüyle sedüler sistemin kişisel olmayan ve objektif bir niteliğe sahip olduğu söylenebilir. Ancak karlarla zararların karşılıklı mahsubu yapılmamakla birlikte, kişisel ve ailevi durumlar da dikkate alınarak çeşitli indirimler yapılabilmekte ve böylece vergi yarı kişisel bir hale getirilebilmektedir (Turhan, 1987: 127; Aksoy, 1998: 329).

Sedüler gelir vergisi sisteminde öncelikle her bir gelir kaynağından ayrı ayrı tek oranlı bir vergi alınmakta, çift elemanlı üniter gelir vergisi sisteminde olduğu gibi gelirin belirli bir miktarı aşması halinde yeniden bir vergilendirme söz konusu olabilmektedir (Turhan, 1987: 129). Ancak aradaki fark, çift elemanlı üniter gelir vergisinde kazanç ve iratların toplamı belirli bir miktarı aşıyorsa sadece aşan kısma artan oranlı bir vergi tarifesi uygulanırken, sedüler gelir vergisi sisteminde aşan kısma değil tüm toplama tamamlayıcı 
nitelikte küresel nitelikli bir vergi uygulanmaktadır (Tosuner \& Arıkan, 2016: 16-17). Yani sedüllü vergilerle global verginin bir arada uygulanması mümkündür. Bu takdirde sedüllerde gösterilmiş gelirlerin toplamına belirli bir miktardan sonra ayrıca impôt général sur le revenu veya surtax gibi adlar altında küresel bir vergi uygulanabilmektedir. Sedüllü vergiler, Latin ülkelerinde uygulanmıştır. Bunun yanında Fransa'da, 1948 yılına kadar 6 vasitasız ve 2 vasitalı vergi, sedüler sisteme göre tahakkuk ettirilmiştir (<www.iktisatsozlugu.com>, 25.11.2015).

Üniter gelir vergisi sistemi sedüler gelir vergisi sistemine göre uygulamaya daha elverişli bir sistemdir. Çünkü sedüler vergi sisteminde mükellefin gelirinin birden fazla vergi rejimine ayrılarak vergilendirmesi halinde, artan oranlı vergilendirmenin ve kişisel indirimlerin (istisna, indirim ve iade gibi) uygulaması zorlaşmakta hatta imkânsız hale gelmektedir (Burns \& Krever, 1998: 2-3).

\subsection{Bileșik Gelir Vergisi Sistemi}

Bileşik gelir vergisi sisteminde vergilendirilecek gelir sedüler vergi sistemine göre yani her bir gelir unsuru ayrı ayrı olmak üzere belirlenir ve belirlenen gelir kaynaklarına farklı, genellikle tek oranlı vergi tarifeleri uygulanır. Eğer toplam gelir belirli bir miktarı aşıyorsa ek bir vergilendirme işlemi söz konusu olacaktır. $\mathrm{Bu}$ aşamada yapılan vergilendirme işleminde vergi; gelir dilimlerinin düşük olduğu artan oranlı bir vergi ya da tek oranlı bir vergi tarifesiyle yapılabilmektedir. Böylece sisteme kısmen de olsa sübjektif bir nitelik kazandırılmaktadır (Ortaç, 2000: 8).

\section{Türkiye'de Uygulanan Gelir Vergisinin Üniter Yapısı ve Bu Yapıyı Bozan Uygulamalar}

Bütün gelir kaynaklarından doğan kazanç ve iratlar ile zararların yıllık beyannamede toplanarak beyan edilmesini ve vergilendirmenin bu şekilde bulunan gelir üzerinden yapılmasını sağlayan üniter sistemin amacı, 1982 Anayasası'nın 73. maddesinde belirtildiği gibi "mali güç ilkesi” nin hayata geçirilmesidir.

Üniter vergi sistemi aynı zamanda, GVK'nın 2. maddesinde belirtilen gelir unsurlarının gerçek ve safi miktarlarının dikkate alınması ilkesi ile GVK'nın 103. maddesinde yer alan artan oranlı vergi tarifesi uygulamasının temelini oluşturmaktadır (Kocaer, 2007). GVK'nın 1. maddesine göre gelir, bir gerçek kişinin bir takvim yılı içinde elde ettiği kazanç ve iratların safi tutarıdır. Türk Gelir Vergisi'nde mükellefler GVK'nın 2. maddesinde yazılı yedi gelir unsurundan bir takvim yılı içinde elde ettikleri kazanç ve iratları kanunda aksine hüküm olmadıkça yıllık beyannamede toplayarak ilgili vergi dairesine bildirirler. Kısacası GVK'nın 85. maddesine göre beyanı gereken gelirlerin yıllık beyannamede toplanması zorunludur.

Türk vergi sisteminde tüm gelir kaynaklarından elde edilen gelirlerin toplanarak tek bir beyannamede ilgili vergi dairesine bildirilmesi, üniter gelir vergisi uygulamasının bir 
sonucudur. Ancak GVK'da yer alan çeşitli uygulamalar üniter gelir vergisi sisteminden sapmalara neden olmaktadır. Aşağıda bu uygulamalara değinilecektir.

\subsection{Beyanname Verilmeyen Haller}

GVK'nın 86. maddesine göre yıllık beyanname verilmeyecek ve diğer gelirler için beyanname verilmesi halinde beyannameye dâhil edilmeyecek gelir unsurları üniter vergi sistemine getirilmiş bir istisnadır. Vergi mükellefleri bazı durumlarda elde ettikleri gelirler için beyanname vermezler. Diğer gelirleri için beyanname verseler bile bu gelirlerini beyannameye dahil etmezler. Örneğin gerçek usulde vergilendirilmeyen zirai kazançlar ile kazanç ve iratların istisna hadleri içinde kalan kısmı, tek işverenden alınan ve tevkif suretiyle vergilendirilen ücretler, mevduat faizleri, faizsiz olarak kredi verenlere ödenen kar payları, menkul kıymetleri geri alım ve satım taahhüdü ile iktisap veya elden çıkarılması karşılığında sağlanan menfaatler, dar mükellefiyette tamamı Türkiye'de tevkif suretiyle vergilendirilmiş olan; ücretler, serbest meslek kazançları, menkul ve gayrimenkul sermaye iratları ile diğer kazanç ve iratlar için beyanname verilmez.

\section{2. İstisna ve Muafiyetler}

Üniter gelir vergisi sisteminin temeli, tüm gelir unsurlarından elde edilen kazanç ve iratların bir arada toplanarak tek bir beyanname ile bildirilmesine dayanmaktadir. Ancak özellikle sosyal amaçlarla bir kısım mükelleflerin vergi kanunları ile vergilendirme dışı bırakılması mümkündür. Yine aynı şekilde bazı vergi konuları da kanunlarla vergi dışı bırakılabilmektedir. Elde edilen kazanç ve iratlar istisna kapsamında ise beyannameye dahil edilmeyecektir. Gelir elde eden kişinin vergiden muaf olması halinde ise yine beyanname verme yükümlülüğü söz konusu olmayacaktır. Bu nedenle Türk Gelir Vergisi uygulamasında yer alan muafiyet ve istisnalar her ne kadar sosyal, iktisadi ve mali amaçlarla uygulansalar da üniter gelir vergisi sistemine ters düşen uygulamalardır. Örneğin sergi ve panayır kazançları istisnası, PTT acenteleri kazançları istisnası, esnaf muaflığı, telif kazançları istisnası gibi Türk Gelir Vergisi sisteminde yer alan muafiyet ve istisnalar üniter yapıya ters düşen uygulamalardır.

\subsection{Stopaj Uygulaması}

Üniter gelir vergisi sisteminde çeşitli kaynaklardan elde edilen gelirler tek bir beyannamede toplanarak vergilendirme işlemi yapılmaktadır. Ancak özellikle kaynakta kesinti uygulamasının gelir vergisinde önemli bir yer tutması, üniter gelir vergisi sisteminden sapmalara neden olmaktadır, yani stopaj uygulaması üniter gelir vergisi sisteminin özüne aykırı bir uygulamadır. Sistemin özü, tüm gelir unsurlarından elde edilen gelirlerin çeşitli indirimlerin yapılması sonrasında kalan safi tutara vergi oranının uygulanmasıyla ödenecek verginin bulunmasıdır. 


\section{4. İhtiyari Beyan Esası}

GVK'nın geçici 67. maddesi kapsamında tevkifata tabi tutulan ve yıllık veya münferit beyanname ile beyan edilmeyeceği belirtilen menkul kıymet ve diğer sermaye piyasası araçlarının elden çıkarılmasından doğan kazançlar için dar mükellefler de dâhil olmak üzere takvim yılı itibariyle yıllık beyanname verilebilecektir.

GVK'nın geçici 67/7. maddesine göre geçici 67. maddenin 1,2,3,4 numaralı bentlerinde yer alan ve tevkif suretiyle vergilendirilen kazançlar için gerçek kişilerce yıllık veya münferit beyanname verilmeyecektir ve diğer gelirler nedeniyle beyanname verilmesi durumunda bu kazançlar beyannameye dâhil edilmeyecektir. Burada yapılan tevkif suretiyle vergileme nihai vergileme niteliğindedir ve vergilendirmenin basitliği sağlanmıştır ancak böyle bir durumda mali güce göre vergilendirme ilkesine aykırı durumlar ortaya çıkabilmektedir. Çünkü tevkif suretiyle vergilendirmede tüm işlemlerden doğan kazançların toplaması yapılmamakta sadece belli bir işlem dikkate alınarak vergilendirme yapılmaktadır. Böyle bir durumda mükellefin kazancı doğmamış olsa bile belli işlemlerinde kazanç elde ettiğinden vergi ödemek durumunda kalabilmektedir (Ecevit, 2011). İhtiyari beyan esas1 temelde mükellef lehine bir uygulamadır. Çünkü mükellef birden fazla menkul kıymet ve diğer sermaye piyasası araçlarını elden çıkarabilir ve hepsinde kar elde etmeyebilir. Böyle bir durumda üniter gelir vergisi sistemine göre zararlar kardan düşülmelidir. İște tevkif suretiyle vergilendirmenin bu sakıncasının ortadan kaldırılmasına yönelik olarak GVK'nın geçici 67/11 maddesi ile geçici 67. madde kapsamında tevkif suretiyle vergilendirilen bazı kazançlar için mükelleflere yıllık beyanname verme konusunda seçimlik bir hak tanınmıştır.

Mükelleflere böylesine seçimlik bir hakkın tanınması üniter gelir vergisi sisteminin özüne ters bir uygulama olarak karşımıza çıkmaktadır. Çünkü üniter gelir vergisi sistemi, tüm kazançların ve kazançlardan mahsup edilecek zararların tek bir beyannamede gösterilmesi esasına dayanmaktadır. Bu nedenle ihtiyari beyan esasının üniter gelir vergisi sisteminden bir sapma olarak nitelendirilmesi yanlış olmayacaktır.

\section{6. Üniter Sistemden Sapmaların Sonuçları}

Türk Gelir Vergisinde yer alan çeşitli uygulamalar gelir vergisinin üniter yapısından sapmalara neden olmaktadır. Bu uygulamalar bir takım sonuçları beraberinde getirmektedir:

- Üniter sistemden sapmalar Anayasamızın 73. maddesinde yer alan "mali güç ilkesi”nden uzaklaşılmasına neden olmaktadır. Çünkü tüm gelirlerin bir arada toplanarak vergilendirilmesi, üniter yapının sağlanması ve ödeme gücüne ulaşılmasında büyük bir öneme sahiptir. Mali güç ilkesinden uzaklaşan bir vergilendirme ise hukuk devleti olma anlayışına ters düşmektedir.

- Yıllık beyannameye dahil edilmeyecek gelirlerin kapsamının geniş tutulması, gelirin toplanması ilkesini ve bu ilkeyle ulaşılmak istenen hedefleri anlamsız k1lmaktadır.

- Gelir Vergisi beyan esasına dayalı bir vergi olmasına karşılık, beyan edilecek gelirlerin kapsamının gün geçtikçe daralması, sistemin amacından sapmasına 
neden olmakta ve Türk Gelir Vergisi stopaj vergisine dönüşmektedir. Gelir İdaresi Başkanlığı verilerine göre 2015 yılı itibariyle gelir üzerinden alınan vergilerin \% 74'ü gelir vergisi iken, \%26'sı kurumlar vergisinden oluşmaktadır. Gelir vergisinin \%93,7'si tevkifat suretiyle \%4,2'si ise beyanname verilmek suretiyle tahsil edilmiş, kalan \%2,1'lik kısmını ise basit usulde gelir vergisi ve gelir geçici vergisi oluşturmaktadır (<www.gib.gov.tr>, 25.11.2015).

- Beyan yoluyla vergilendirmenin mükellef açısından getirdiği zorluklar kayıt dışılığın artmasına ve sonuçta stopaj yoluyla vergilendirmenin ağırlık kazanmasına, beyan-stopaj esaslı karma bir sisteminin ortaya çıkmasına neden olmakta ve sistemin özünü bozmaktadır.

- Gelir vergisinde vergilemenin esas itibariyle mükellefin beyanına ve gerçek gelirine göre yapılması gerekirken, aksine vergileme "mükellefin beyanı"na göre değil, "aracının beyanı"na göre yapılmaktadır. Bazı durumlarda mükelleflere bir takım kolaylıklar sağlayabilmek ve işlemleri hızlandırabilmek adına şahsen beyan verme zorunluluğunun olmaması pratik olabilir. Ancak esas prensip, mükellefin kendi vergisini vergi idaresine bizzat kendisinin ödemesidir. $\mathrm{Bu}$ nedenle ödeme yükümlülüğünün mükellefler tarafından değil de aracılar vasitasıla yerine getirilmesi (ücretlilerin gelirlerinin vergi sorumlusu niteliğindeki işverenler tarafından kaynakta kesilerek vergi dairesine yatırılması gibi), bilinçsiz ve ilgisiz bir mükellef kitlesinin oluşumuna ortam hazırlamaktadır. Stopaj yoluyla vergi ödeyen ve ödediği gelir vergisini ve katlandığı vergi yükünü bilmeyen çok sayıda mükellef bulunmaktadır.

- Üniter sistemden sapmalar genellik ve eşitlik ilkelerinden de sapmalara neden olmakta ve adalet anlayışından gittikçe uzaklaşılmaktadır.

- Gelir vergisinde yer alan üniter sistemden sapmalar, vergilendirmede artan oranlılığı da olumsuz bir şekilde etkilemektedir. Zira bu uygulamalar nedeniyle artan oranlı gelir vergisi tarifesindeki artan oranlılı̆̆ın şiddeti azalmaya başlamış ve bu durum gelir vergisinin artan oranlılık yönünden sübjektiflik (şahsilik) özelliğini bozmaya başlamıştır. Beyannamede gösterilen gelir kapsamının daralması, artan oranlı gelir vergisinin anlamını kaybetmesine neden olmaktadır. Dolayısıyla subjektif özelliği en baskın vergi türü olan gelir vergisinin bu özelliği etkisini kaybetmektedir.

- Üniter sistemden sapmalar vergi gelirlerini de olumsuz etkilemekte ve kimi mükelleflerin haklarının zedelenmesine neden olmaktadır. Üniter sistemden sapmalar beyan yoluyla vergilendirilen birçok mükellefin kayıtdışılığa yönelmelerine ve peçeleme işlemelerinin artmasına neden olmaktadır. Böylelikle tam olarak uygulanamayan beyan yöntemi, re'sen ve ikmalen tarhiyat yoluyla tamamlanmaya çalışılmaktadır.

- Üniter sistemden sapmalar vergiye gönüllü uyum konusunda mükelleflerin isteklerinin azalmasına ve böylelikle vergilendirilebilir gelirin kapsamının daralmasına ve dar tabanlı bir vergilendirmenin oluşumuna ortam hazırlamaktadır. 


\section{Sonuç ve Öneriler}

Dünyada gerek gelişmiş gerekse gelişmekte olan ülkelerde devlete yüklenen görevlere paralel olarak vergi yükleri de sürekli değişmekte ve kesimler arasında yön değiştirmektedir. Artan devlet fonksiyonları ve kamusal ihtiyaçlar vergi gelirlerini yetersiz hale getirdiğinden, kimi ülkeler yeni vergiler ihdas etmeyi ya da mevcut vergilerin oranlarını arttırmayı tercih ederken, kimi ülkeler de vergi oranlarını azaltarak, vergiyi tabana yayarak ekonomik büyümeyi sağlamaya ve vergilendirmeden optimal bir hasılat elde etmeye ve artan gelir kaybını telafi etmeye çalışmaktadırlar.

Vergi sistemimizde vergisel gelirin tam olarak kavranamamasının yani vergi kaybının temelini, istisna ve muafiyet uygulamalarının gereğinden fazla olması, gelirin doğmasına karşılık gelir unsurlarına girmemesinden dolayı vergi konusu da dâhil edilememesi nedeniyle vergilendirilememesi yani teorik olarak tanımlanan gelir tanımına uygulamada ulaşmanın zor olması, üniter yapıdan sapmalar, denetim yetersizliği ve vergi bilincinin gelişmemesi, cezaların caydırıcı olmaması gibi faktörler oluşturmaktadır.

Türk Gelir Vergisi sisteminde beyan esası ve beyannamede gelirlerin toplanması ilkesi temelde geçerli olmasına karşılık, verginin stopaj usulü ile toplanması ve yıllık beyannameye dâhil edilmeyecek gelirlerin kapsamının aşırı geniş tutulması nedeniyle, gelirin toplanması zorunluluğu anlamını kaybetmekte ve üniter yapıdan sapmalar meydana gelmektedir. Bu durum, sistemde artan oranlı gelir vergisi tarifesinin anlamını yitirmesine ve ödeme gücünden uzaklaşılmasına neden olmaktadır.

Türk Vergi Sisteminde adil ve mükellef haklarını zedelemeyecek şekilde gelirin kavranması gerekmektedir. Bu nedenle yapılması gerekenler şunlardır:

- Türk Vergi Sisteminde beyan ağırlıklı geniş tabanlı bir vergilendirmeye ağırlık verilmesi gerekmektedir. Beyannameli mükellef sayısı artırılmalıdır.

- Ücretlilerin büyük ölçüde stopaj usulü ile vergilendirilmesi, beyanname verilmesine izin vermeyen düzenlemelerin olması ücretliler üzerindeki vergi yükünün artmasına ve bu kesimin vergi yükü altında ezilmesine neden olmaktadır. Ücretli kesim beyan kapsamına sokulmalıdır.

- Beyan yoluyla vergilendirmeden uzaklaşıp stopaj yoluyla vergilendirmeye yaklaşmak, vergi denetimindeki eksikliğin ve yetersizliğin bir sonucudur. Beyan sisteminin geniş ve etkin denetimli bir hale getirilmesi önemlidir. Kısacası "Kontrollü Beyan Sistemi” yaygınlaştırılmalıdır.

- Siyasi ve ekonomik bir tercih sonucu harcamalar üzerinden vergi alınmasi eğiliminin artması, gelir üzerinden alınan vergilerin önemini azaltmamalı ve gelir üzerinden alınan vergilerde denetimi artırıcı ve destekleyici vergi güvenlik müesseseleri getirilerek sistem desteklenmelidir.

- Türk Vergi Sisteminde safi artış teorisine uygun bir anlayışla geliri geniş bir şekilde kavrayacak bir vergilendirme için gerekli kanuni düzenlemelerin yapılması, altyapı çalışmalarının tamamlanması, mükelleflerin söz konusu 
değişikliklere hazırlanması ve hepsinden önemlisi vatandaşın verginin sadece kendisinden değil herkesten tam, doğru, adil bir şekilde alındığına ve harcandığına inandırılması gerekmektedir.

- Gelirin ekonomik ve hukuki olarak tanımlanmasının yanında mali gelir kavramına da yer verilmesi ve üzerinde durulması gerekir. Türkiye'de geliri mali anlamda kavramak için elektronik beyan, bankacılık sistemindeki gelişmeler ve idari düzenlemeler önemli gelişmeler olmasına karşılık istendiği gibi kavranmasında yeterli olmamaktadır.

- Geliri geniş bir şekilde kavrayabilmek için etkin bir denetim ve muhasebe sisteminin varlığ 1 ve işletilmesi gerekmektedir.

- GVK'nın 86. maddesinde yer alan beyannameye dahil edilmeyecek gelirlerin ve stopaj uygulamasının kapsamı minimum düzeye çekilmelidir.

\section{Kaynaklar}

Aksoy, Ş. (1998), Kamu Maliyesi, Filiz Kitabevi, İstanbul.

Arslan, M. (2012), Türk Vergi Sistemi, Nobel Yayınevi, Ankara.

Bayraklı, H.H. (2000), "Gelir Vergisi Kanununda Gelir Kavramı ve Sapmalar”, Mevzuat Dergisi, 3(36), Aral1k, <http://www.mevzuatdergisi.com/2000/12a/02.htm>, 15.09.2015.

Bulutoğlu, K. (1976), Türk Vergi Sistemi, Fakülteler Matbaası, İstanbul.

Burns, L. \& R. Krever (1998), “Individual Income Tax”, in: Tax Law Design and Drafting, ed. Victor Thuronyi, Volume: 2, Chapter: 14, International Monetary Fund, 1-67.

Ecevit, Ö. (2011), "GVK Geçici Md. 67 Kapsamındaki Kazançlar İçin Uygulanan İhtiyari Beyan Müessesesi”, Yaklaşım, S. 219,

$<\mathrm{http} / /$ Uye.Yaklasim.Com/Magazinecontent.Aspx?Id=12385\&Aranankey=İhtiyari\%20b eyan> 29.09.2015.

Erginay, A. (1998), Kamu Maliyesi, Savaş Yayınları, Ankara.

EY (2015-2016), Worldwide Personal Tax Guide, <http://www.ey.com/Publication/vwLUAssets/Worldwide_Personal_Tax_Guide_201516/\$FILE/Worldwide\%20Personal\%20Tax\%20Guide\%202015-16.pdf>, 31.05.2016.

Ferhatoğlu, E. (2003), “Gelir Teorileri Bağlamında Avrupa Birliği Ve Türkiye'deki Gelir Tanımlaması ve Sonuçları: Karşılaştırmalı Bir Analiz”, e-Akademi, S. 19, Eylül, <http://www.e-akademi.org/makaleler/eferhatoglu-1.htm>, 28.08.2015.

Hamaakers, H. (2003), "Taxation Trends in Europe”, Asia-Pacific Tax Bulletin, 42-50.

Kocaer, Ş. (2007), "Yıllık Beyanname İle Beyan Edilecek Gelir Unsurlarının Tespitinde Vergiye Tabi Gelir Toplamı Kavramı", Vergi Dünyası, S. 310, Haziran, <http://www.vergidunyasi.com.tr/>, 10.10.2015.

Nadaroğlu, H. (1996), Kaти Maliyesi Teorisi, Beta Basın Yayım Dağıtım, İstanbul.

Ortaç, F.R. (2000), Gelir Vergisinin Üniter Yapısı, Gazi Kitabevi, Ankara.

Öncel, M. \& A. Kumrulu \& N. Çağan (2012), Vergi Hukuku, Turhan Kitabevi, Ankara.

Özbalcı, Y. (2008), Gelir Vergisi Kanunu Yorum ve Açıklamaları, Oluş Yayıncılık, Ankara. 
PKF (2013), Portugal Tax Guide 2013, <http://www.pkf.com/media/1958975/portugal\%20pkf\%20tax\%20guide\%202013.pdf>, 01.06.2016.

Saraçoğlu, F. (2000), "Vergi Erozyonu Açısından Gelir Vergisinde Yer Alan Müesseselerin Analizi”, Gazi Üniversitesi I.I.I.B.F. Dergisi, 2/2000, 79-96.

Şenyüz, D. \& M. Yüce. \& A. Gerçek (2015), Türk Vergi Sistemi, Ekin Yayınevi, Bursa.

Tosuner, M. \& Z. Arıkan (2016), Türk Vergi Sistemi, Kanyılmaz Matbaası, İzmir.

Turhan, S. (1987), Vergi Teorisi ve Politikası, Der Yayınları, İstanbul. 